to such an extent by the accumulation of detritus at the head of the canal that the irrigation com pany determined to secure another supply rather than go to the enormous expense of dredging the clogged canal head. With this idea in view, they a few miles below the head of the Alamo channel, connecting it with the Colorado. This work was completed in November, 1904. The excavation was merely a ditch less than a mile in length and about fifty feet in width, but a flood which occurred a few weeks after it was completed enlarged it to such an extent, that a considerable volume of the water in the river began flowing through it into the main canal. The flow of water was too great to be absorbed by the irrigation system, and as already stated, it worked its way along the lower Alamo chan nel to the Salton Sink, into which it is still flowing. Owing to the friable formation of the river banks a the head of the new channel, and the force of the cur rent during flood season, it was found impossible to prevent the ditch from being enlarged to such an exprent that within six month after the arst tent that within six months after the first crevasse being diverted in a northwesterly course into the Sink. The greatest volume of water in the river is usually during the months of June and July, when the drainage from the mountains along the upper river and its tributaries is greatly increased by the melting snow and ice. Measurements taken by engineers in July last showed that no less than 25,000 cubic feet per secon were flowing through the new channel. Since then there have been times when the river bed between the channel and the Gulf of California has been practically dry, ex c e p when the river was abnormally high. The effect o the current aided by the erosion of the sediment held in solution enlarged the new channel from its original dimensions to a width varying from 600 to no less than 2,000 feet in some places, and considerably deepening it. As a result, the water contained in the Salton Sink has the Salton sink has been steadily increasing, un til fears have been en tertained lest the entire valley between the San Jacinto and San Ber$\mathrm{n}$ a rdin o mountains, which inclose which inclose the Sink on three sides, will be flooded. Recent meas urements of this new sea which is forming show that it is at pres ent about 50 miles in length, having a maximum depth of about 25 mum depth of about 25 feet. The daily increase in $\mathrm{de} \mathrm{pth}$ varies of quantity coming down the river, but it has

been as high as nearly three inches in twenty-four hours, varying from this to three-fourths of an inch. While the salt industry has been practically ruined by the flood, as yet the irrigated district has not been harmed, owing to its elevation. The basin must be filled to a maximum depth of at least 150 feet before the water would cover the farms of the Imperial Valley. Consequently a period of years would elapse before the irrigation district would be affected; but the heaviest loss is that of the Southern Pacific Railroad, for it has been is that of the Southern Pacific Railroad, for it has been
compelled to alter the location of its roadbed, and rebuild about fifty miles of track at a greater elevation to prevent it from being submerged.

The question of confining the river to its ordinary channel presents a somewhat difficult engineering problem. Soon after the Colorado began flowing through the new channel, an attempt was made to change the course of the current to the south by a diverting wall made of brushwood fastened with wire and reinforced by gravel. A sudden rise in the river carried thi away in a few hours, and created conditions which were worse than before. An attempt was also made to lead the water into the Padrones channel, thence into Volcano Lake, but this was unsuccessful, the rive forming another channel between the Padrones and the Alamo and continuing on to the Sink. The final plan determined upon, which is now being carried out, is the construction of two massive barriers, one protecting the head of the original channel, and the other the head of the channel through which the river has changed its course. The first barrier, which will be 175 feet in length, is being built of concrete and steel on a rock foundation, and contains head gates whic will allow a sufficient volume of water to flow into th canal for irrigation purposes if desired. The lowe work is about 200 feet in length, also composed of concrete and steel, but is being constructed in connection with wing dams and levees of timber and earth. This is also provided with gates. The concrete and steel portion of the barrier is being built at such an angle that it will offer the principal resistance to the flood currents, while the dams and levees are intended to prevent the bank from being washed away by eddies or other back water. It is expected that the two bariers will be completed before the summer floods reach the lower river, the engineers working partly on the the ory that the mass of silt which will be carried down at this time will tend to scour out the original channel, an aid in confining the volume of water. In sh'ort, the principle is the same as has been so successfully employed in the deepening of the Mississippi near its mouth by the construction of the jetties, the river partly makin its own channel. Since the Colorado has been flowin into the northwest passage, its former bed has been steadily filling up by the accumulation of sediment in the vicinity of the cut-off. If the flood currents remove this deposit, it is believed that the work which is now being done will permanently keep the river in its original course, and prevent further flooding of the the tablet suggested the square into which it soon develope

Side by side with the evolution of the square tablet from the clay ball, a similar tablet was developed from the early building brick. The first Dabylonian brick was rectangular; its sides were plano-convex-plane on the bottom where it rested upon the ground to dry, and convex on the surface, because while drying the edges ran down the sides. To the first tablets which were not spherical or nearly so, this plano-convex form was imparted, but the convex side became less convex, and by 3800 B. C. both sides were nearly alike, and its form became identical with the tablets which developed from the clay ball. The tablet, square or nearly so, retained its shape for a considerable period; but if the inscription to be recorded upon it was long, the length of the tablet was increased, while its width remained practically the same. This elongated form of the square tablet thus became the standard for all of the later ages of the Babylonian empire.

In size the tablets vary exceedingly. While some measure hardly more than half an inch in length, others are fully eighteen inches long and a foot wide, yet the average of the hundreds of thousands of Babylonian tablets which are now in the museums of Europe may be not far from three inches in length and half as wide.

Although the rectangular form of the clay document prevailed, other shapes were adopted for special purposes as occasion demand. ed. The schoolboy's exercise tablet was invariably round, and the clay labels which were attached to merchandise were eggshaped and their longer diameters were pierced with a hole for the string. An exceedingly interesting form of tablet was that given to the Babylonian letter of 2400 B. C. and later. The clay of the letter was molded and in. scribed as were the or. dinary business documents, and when finished, a thin coating of clay was wrapped about it, serving as an envelope to protect the writing within, or to con. ceal it from the eyes of the curious. The envelope was then stamped with the seal of the writer, or sometimes engraved with a few words, and the letter with its envelope was
placed in the sun to dry, or in the furnace for baking. It was then ready for delivery.

The discovery of these early documents at Bismya has not only revealed the origina? form of the tablets, but has also assisted in explaining the development of the cuneiform

LETTER WRITING FIVE THOUSAND YEARS AGO

valley to the northwest. A more complete account of the dams which are now in course of construction, an which are intended to control the Colorado River, will appear in next week's Scientific AMERICAN.

\section{LETTER WRITING FIVE THOUSAND YEARS AGO.}

While Babylonian clay tablets of various forms an sizes have been known and collected by the large European museums for fully half a century, it is only in recent years that tablets of an exceedingly ancien date have been found in sufficient numbers to reveal their origin and early development. Of the two thousand tablets discovered in the Babylonian ruin Bismya by the expedition of the University of Chicago, a large proportion of them date from the fifth millennium $B$. C and present such a variety of shapes and sizes that their origin has for the first time been ascertained. The first Babylonian tablets, and therefore the old est written documents in the world, were of clay. Th original shape was round like a ball, and in size it re sembled a small nrange. The early scribe drew upon the soft clay the rough pictures by which his language was expressed, and then placed the written document in the sun to dry. As writing became more common the tablet lost its spherical shape and the inscriptio was confined to its flattened sides. A number of such tablets, almost spherical, came from Bismya. As the centuries passed, the sides became flatter, corners began to appear in the circular edge, and by $4000 \mathrm{~B}$. C or wedge-shaped writing. How does it happen that the Babylonians committed their thoughts to writing by
stamping combinations of wedges upon clay? The stamping combinations of wedges upon clay? The
wedge is an accidental result of the use of clay. The wedge is an accidental result of the use of clay. The very earliest inscriptions, found mostly upon stone vase iragments, are not composed of wedges, but of straight lines. The Babylonians first wrote by drawing pictures of the objects which were in their minds. In time the pictures became conventionalized, as is the case with Chinese, and the original objects could no longer be recognized. When clay was substituted for stone, it was difficult to draw an even straight line upon it, for the edge of the style which first touched the clay sank deeper, leaving a wedge-shaped impression. The wedge hus arose; and as clay was practically the only material employed by the scribe, the wedge became so thoroughly identified with the language, and the old inear writing was so entirely forgotten, that during the last three millenniums of the Babylonian empire, the scribes, even when engraving upon stone, gave their characters a wedge-shaped form.

An engineering firm at Pittsburg has patented a new type of universal plate mill, and has received a contract from the Illinois Steel Company for the building of one driven by an electric motor of 6,000 to 8,000 horsepower capacity, this being the first time that a mill of this character and size has been electrically driven. of these mills at South Chicago. The mill will be 